\title{
三次元視覚センサによる自動車パネル寸法検査システム
}

$\begin{array}{llllll}\text { 正員 樋 } & 口 & \text { 和 } & \text { 則 } & \text { (豊田中研) } \\ \text { 正 員 小 } & \text { 関 } & & \text { 修 } & \text { (豊田中研) } \\ \text { 正 員 山 } & \text { 本 } & & \text { 新 } & \text { (豊田中研) }\end{array}$

\section{Inspection System for Automotive Body Panel Dimensions using a 3-D Vision Sensor}

Kazunori Higuchi, Member, Osamu Ozeki, Member, Shin Yamamoto, Member (Toyota Central Res. \& Develop. Labs., Inc.)

An algorithm for inspecting the dimensions of automotive body panels using a three-dimensional (3-D) vision sensor has been developed, together with an inspecting system based on this algorithm. The slit light of the 3-D vision sensor is projected onto the body panel and the reference block which gives reference coordinates. In order to measure the gap and flushness between the panel and the block, this algorithm estimates the edge of the bent panel by fitting a circle on the image from the sensor. Further the image is improved by controlling both the projection angle and brightness of the slit light, when the disconnected slit light image is obtained.

The system measured the gap and flushness with accuracy to $\pm 0.15 \mathrm{~mm}$ in the experiments and proved effective for the inspection of panel dimensions.

キーワード : 三次元視覚センサ, 寸法検榅, 光切断法, 自動車パネル

\section{1.まえがき}

自動車の高級化指向に伴って，自動車ボディの仕上 り品㯲向上への要求がますます大きくなっている。自 動車ボディの任上り寸法品筫は, 自動車の塗装品質と 並九で重要な仕上り品質の一つである。

自動車ボディは，ボディを楧成する各部のパネルを 組合せてボディきょう体とし，それに種々の部品を取 付け, 染装を施した後, 完成車となる。そのため, 自 動車ボディの検查は，ボディを構成する各部のパネル での検查, 㳊装する前のボディきょう体で検査, お よび完成車雨での最終検查に分けられ，各工程で非常 に綿密な検查が行われる。

ボディきょう体での検㚗には，各パネルを組付けた ボディの諸元の寸法計測, 各パネルの組付け寸法の検 査, および空ガラスを装着するための位置の検出と榆 查などがある。このうち, ボディ諸元の寸法計測で
は，検㚗するボディの凮側に設置した6 軸ロボットの 先端にスポット光センサを装着し、ロボットを動かし てきょう体の諸元を計测した報告がある(1)。また，口 ボットを用いず固定治具に多くのセンサを取付けて莬

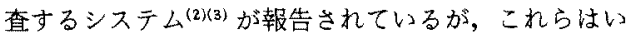
ずれもスポット光センサによる検查で, 計測部位も単 純な形状をしたものに限られている。

完成車両の最終㭘查については, 検查員による綿密 な検查が行われていて，検査の自動化の強い要望があ るが，これまでに検查システム開発の報告はない。

パネル検查は，端部に丸みをもつパネルの仕上り寸 法を検查するもので，これらについても開発報告例は 見あたらない。

自動車ボディではなく各種の部品や素材の寸法や形 状の検查については，スポット光と PSD（半導体位 置検出器) を組合せた形状険查システム(4)(5)や，スポ ット光を一次元走查して得た二次元同期走查型セン 
$サ^{(6)}$ を用いた形状計測システムや、スリット光を用 いた船舶用プロペラの形状検查システムの報告(7) も あるが，いずれも端部形状が複雑でなく，寸法や形状 検査のための新しい工夫はなされていない。また，著 者らによる十字スリット光形三次元視覚センサを用い たエンジン用自動車部品の寸法検査システムの報告(8) がある。これは，十字スリット光により突起や穴の寸 法や非対称性を検查するために開発されたもので，自 動車パネルのように曲がりのある端部の寸法検查への 適用は考之られていない。更に，自動車パネルの上う に表面に光沢が生じやすく，そのため反射光画像に途 切れが生じやすい対象物への適用は難しい。

著者らは，端部が規定の曲率で曲げられた自動車パ ネルの寸法を, 光切断法による三次元視覚センサを用 いて検查する方法と，この方法による自動車パホル寸 法検査システムを開発した。

この検査方法は, 精密に製作された基準となる治具 （以下，基準ブロックと呼ぶ）に沿わせて検查すべきパ ネルを位置決めし，それらにスリット光を投射し，そ の反射光画像加パネルと基準ブロック間の幅（以 下，すき間と呼ぶ）と高さの差(以下，段差と呼ぶ）を 得るもので，パネル端部の非状がある曲率で曲げられ ているにもかかわらず，安定してすき間と段差を計 測・検查するものである。更に，端部に光沢などが発 生して反射光画像に途切れが生じても，投射するスり ット光の角度制御と投射強度制御によって反射光画像 の䁈を良くして検査できるようにしている。

この方式を用いた自動車パネル寸法検査システム は，上記の方式をロボットとマイクロコンピュータな どで制御しこれまで人手などによって行われていた 検查を自動化することにより，検査品質の向上と大幅 な省人化が達成された。

本論文では, 第 2 章で恰查方法を, 第 3 章で三次元 視覚センサを含む検查システムの構成を, 第 4 章で検 查システムを用いてこの検查方法の有效性とシステム の性能について述べる。

\section{2. 検查方法}

〈2・1〉検查対象自動車ボディは,ドア部パネ ル，エンジンフード部パネル，トランクフード部パネ ル，フェンダ部パネル，などの各部のパネルで構成さ れている。検查すべき対象は，これら各部のパネル でここれらのパネルには防銿鋼板が用いられている。

図 1 はフェンダ部パネルを示したものである。パネ ルの端部は, 多くのものが規定の曲率で曲げられてい る。模㚗は製作されたパネルが設計值どおりに作られ

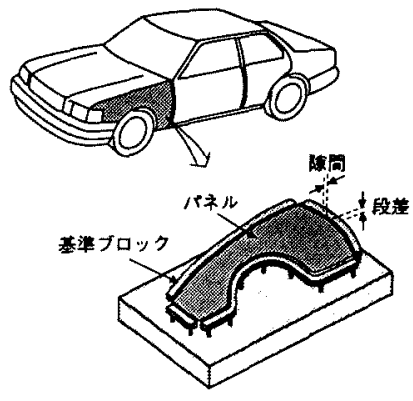

図 1 自動車パネル

Fig. 1. The automotive body panel.

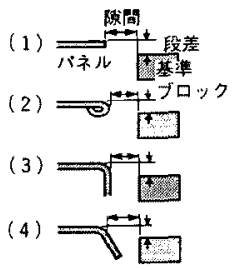

図 2 代表的なパネル端部の形状

Fg. 2. Shapes in the edge of typical panels.

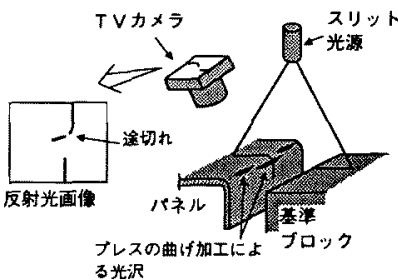

図 3 パネル端部の計測と光沢による 反射光画像の途切几

Fig. 3. Measurement of the panel edge and disconnected slit light image by the gloss in the edge.

ているかをみるもので，精密に製作された基準ブロッ クを標準として，検査すべきパネルと基準ブロックと の間のすき間や段差を計測することによって行われ る。

自動車の各部のパネルの端部はそれぞれ翼なった形 状をしている。図 2 はその代表的な端部形状を示した もので，その形状は図のように，(1)パネル端部が切 断されている場合，(2)パネルが内側に曲げられてい る場合，(3)パネルが直角に曲げられている場合，お よび(4)パネルが鈍角に折曲げられている場合の四つ に分けられる。すき間と段差は，各場合について図の 
ように定義されているので，それぞれの定義された点 を検出するのが課題となる。また，(2)〜（4)の場合 には，鋼板をプレス曲げ加工することにより，その一 部分が伸びて，その端部の表面に光沢などが発生する ことがある。

上述の端部形状をしたパネルを高速に検査するため には, 光学的手法が有効と考元られ, その具体的な方 法として，スリット光を投射してその反射光を TV カメラで撮像する方法がある。この方法を用いる場 合, 図 3 に示すようにスリット光をパネルと基準ブロ ックの閪に投射すると, プレス曲げ加工によって発生 する光沢などのために，TV カメラの反射光画像に途 切れが生ずる。このように，途切れの発生などのため に正確な画像が得られないと, 図 2 に示した各種のパ ネル端部形状に対し正しい検査が行えなくなる。正確 な検查のためには，途切れのない画像を得ることが必 要となる。

〈2・2〉基本検查方式 考案した検查方式は，娭 查すべきパネルと基準ブロック間にスリット光を投射 して, その反射光画像に最適な円をあてはめ, その円 弧の端点（以下，才法定義点という）を推定算出し, 曲率が種久変わる端部形状のパネルについても, 正確 なすき間と段差を計測する方式である。更に, 曲げ加 エによって生ずる光沢のために反射光画像に途切れが 発生したときには，スリット光の投射角度制御と，投 射強度制御併用し, 途切九のない画質の良い反射光 画像に改善して検查する。

図 4 怡反射したスリット光画像から寸法定義点を求 める方法を示した図である。検査部位にスリット光を 投射して得られる反射光画像から三次元座標を検出
し，パネル端部の曲け゚の部分（以下，円弧部と呼ぶ） に円をあてはめて算出された円の中心と半径加ら寸法 定義点を決定する。ここで, 円弧部は, 図4に示すよ うにパネル断面の三次元座標值の二次微分, すなわち 曲率を計算し，曲率が許容值以上の長さにわたりしき い值を超える領域として検出する。また，図2（1）の ように円弧部がない場合には, 画像上の端点を寸法定 義点とする。

図 5 は，反射光画像の途切れを改善するための投射 スリット光の投射角度制御と投射光強度制御の方法を 示したものである。同図は，円弧部のプレスによる光 沢などのために, スリット光画像の反射光量が低下 し, 結果として (a)図に示すように三次元座標値に途 切れが発生する。投射角度と, 投射光強度の制御を行 うためにまず着目すべきパネル端部の円弧部を抽出 する。

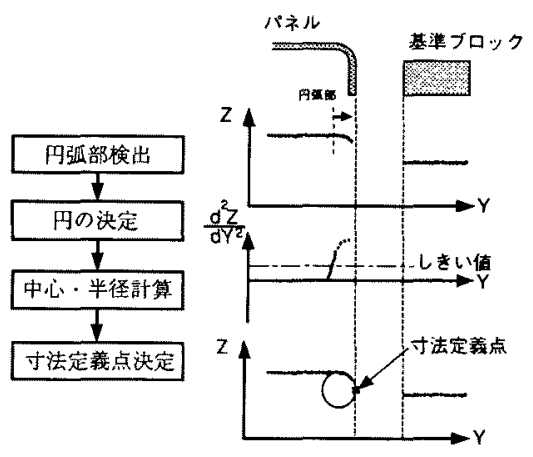

図 4 円弧近似による寸法定義点の決定 Fig. 4. Determination of the dimensional characteristic point by fitting circle.
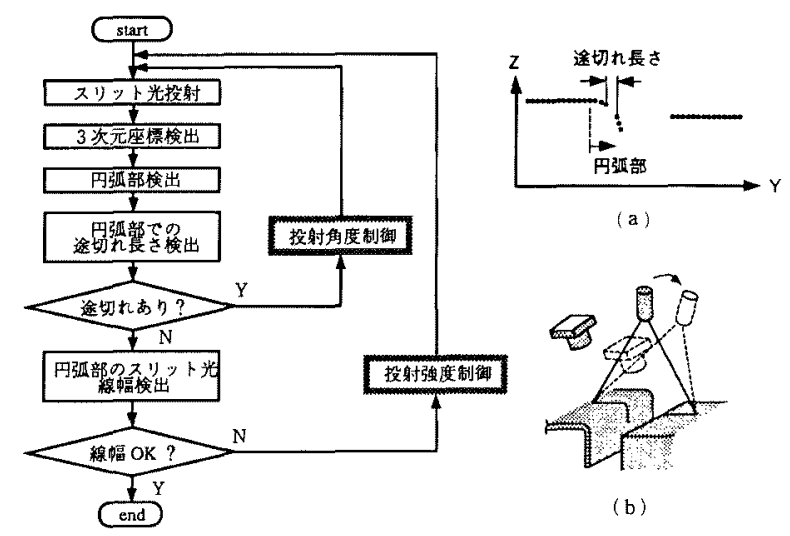

(a)

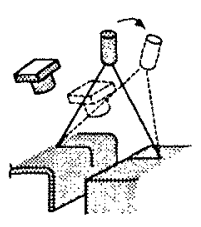

(b)

図 5 スリット光の投射角度と投射強度の制御

Fig. 5. Algorithm of controlling the slit light angle and brightness to be projected. 
次に，円弧部において三次元座標值から途切れの長 さを検出し，途切れがあった場合には，センサの姿勢 を制御して，スリット光を投射する角度を微小位置だ け移動させる。このとき，センサの移動方向は, 投射 スリット光平面内で，パネル端部をのぞき込む方向の 角度を制御する。この状態で，同様にスリット光を投 射し，途切れの長さを検出する。ここでスリット光の 途切れが小さくなれば，前回移動した方向と同じ方向 に更に移動させ，逆にスリット光の途切れが大きくな る場合には, 前回の移動の逆方向に移動させる。この 投射角度制御により，途切れのない品質の良いスりッ 卜光画像を得ることができる。

次に, 円弧部のスリット光の線幅を検出し，これが 適正な範囲にあるかどうかにより投射光強度制御を行 う。すなわち, 円弧部のスリット光の線幅が小さすぎ る場合には，投射光強度を上げ，逆に線幅が大きすぎ る場合には，投射光強度を下げる。ここで，直線部の スリット光の線幅も同時に検出し，これが許容範囲を 超えない範围で投射光強度を制御する。直線部のデー 夕は円弧部の検出と段差の計測のために用いられる。 直線部ては，すき間の計測のようにスリット光の端を 検出する場合に比較して, スリット光の線幅の影響は 小さくなるため線幅の許容範囲を広く設定できる。従 って, 投射光強度の制御では, スリット光の線幅の適 正な範囲を直線部と円弧部で別々に設定できるため, 実用上の問題はない。

このように，投射角度と投射光強度を制御すること で，途切れの少ない均一な画像を得ることができる。

〈2・3〉検查アルコリリズム図6は検查の処理の 流れを示したものである。まず，センサを計測すべき

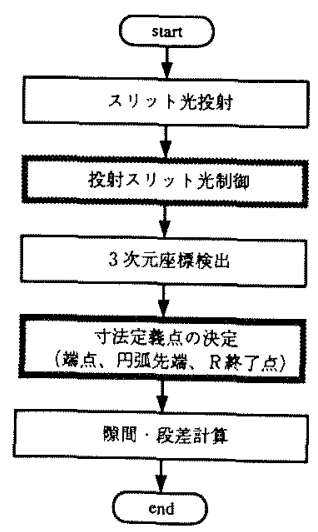

図 6 検査の処理の流れ

Fig. 6. Flow chart of dimension inspection.
部位に位置決めし，スリット光を投射する。このと き, 途切れのないスリット光画像を得るために, 前述 したパネル端部に着目した投射角度と投射光強度を制 御する。次に, 三次元座標を検出し，端部形状に応し て，すき間と段差を決定する寸法定義点を決定して， すき間と段差を計算する。ここで，寸法定義点は，パ ネルの設計上，図2（1）では，すき間・段差ともパネ ルの先端, 図 2(2)（3)では, すき間は円弧部の先 端, 段差は円弧開始点, 図 2(4)では, すき間は円弧 終了点, 段差は円弧開始点と決められている。

\section{3. 検査システム}

〈3・1〉 三次元視覚センサパネル寸法検查のた めに三次元視覚センサを新しく開発した。図 7 に,こ の視覚センサの構成を示す。この視覚センサは, 光奶 断法を用いた三角測量により三次元座標を検出する。 この視賞センサは, 撮像へッドと奉時間の座標測定を 行うための座標演算ボードで構成されている。

撮像ヘッドは，スリット光源と TVカメラからな る。スリット光は, 半導体レーザのスポット光を円筒 レンズで変換して得ている。レーザの波長は，一般の 照明の影響を受けないように近赤外の $830 \mathrm{~nm}$ に選ん でいる。TVカメラは，384 (水平) $\times 484$ (垂直) 画 素の小形 CCD カメラを用いている。

座標演算ボードは, TVカメラの撮像素子上のスリ ット光画像の位置を検出するスリット光中心位置検出 回路，この位置を三次元座標值に変換するためのルッ クアップテーブル，および対象物の表面性状の影響を 低減するための投射光強度制御を行うスリット光反射 強度検出回路とスリット光投射強度設定回路からな る。これら回路は，実時間の座標測定を行うために， すべて専用ハードウェアで構成されている。

図 8 にこの三次元視覚センサの外観を示す。

表 1 はこの三次元視覚センサの性能である。測定範 囲は, センサの先端から $70 \mathrm{~mm}$ の位置で $30 \mathrm{~mm}(Y)$

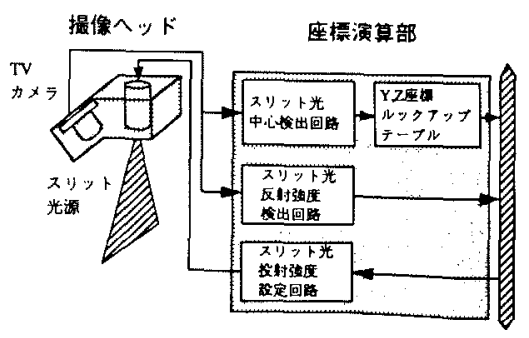

図 7 三次元視賞センサの構成

Fig. 7. Block diagram of 3-D vision sensor. 


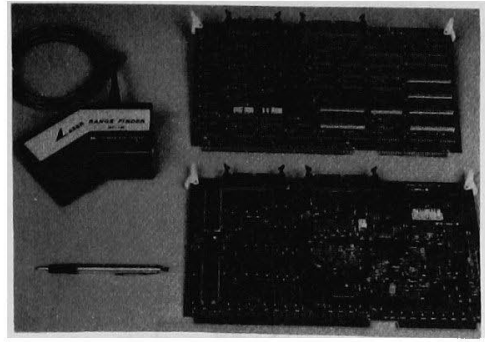

図 8 三次元視覚センサの外観

Fig. 8. Photograph of 3-D vision sensor.

表 1 三次元視覚センサの性能

Table 1. Performance of 3-D vision sensor.

\begin{tabular}{c|l}
\hline 動作距離 & $70 \mathrm{~mm}$ \\
計測䡉囲 & $30(Y) \times \pm 10(Z) \mathrm{mm}$ \\
計測点数 & 484 点 \\
計測精度 & $\pm 0.06 \mathrm{~mm}$ \\
計測時間 & $33.3 \mathrm{~ms} / 484$ 点 \\
\hline
\end{tabular}

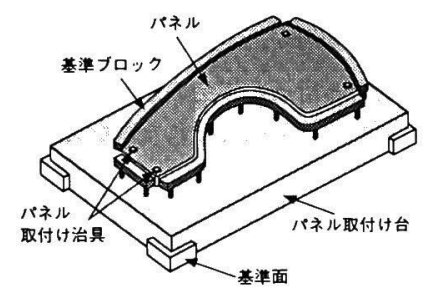

図 9 パネル取付け台の構成

Fig. 9. Schematic diagram of panel attachment table.

$\times \pm 10 \mathrm{~mm}(Z)$, 測定精度は $\pm 0.06 \mathrm{~mm}(Y, Z)$ であ る。測定点数はスリット光に沿って 484 点, 測定時間 は実時間座標測定により 484 点につき $33.3 \mathrm{~ms}$ であ

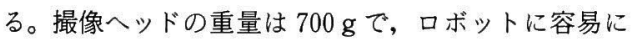
装着できる。

〈3・2〉 システムの構成 開発した検査システム においては, パネルはパネル取付け台に取付けられて 検查される。図 9 にパネル取付け台の構成を示す。こ の取付け台には，対象パネルに対応した基準ブロック が固定されており，パネルは，この取付け台に磁石を 用いた専用の取付け治具で取付けられる。また,この 取付け台の側面と底面には，パネルを検査システムへ 正しく位置決めするための基準面が設けられている。 この取付け台は, 各種パネルを検査システムに簡便か つ正しく位置決めするために, パネルの種類によらず 共通の仕様て作られている。

図 10 に開発したパネル寸法検査システムの構成を 示す。このシステムは, 三次元座標を検出するための

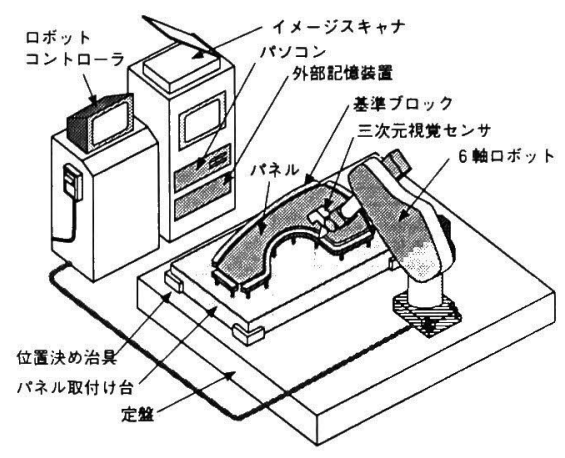

図 10 検査システムの構成

Fig. 10. Schematic diagram of the inspection.

三次元視覚センサ, 三次元視覚センサを計測部位へ移 動・位置決めするための 6 軸ロボット，6軸ロボット を制御するためのロポットコントローラ, 三次元視覚 センサの出力の処理ほかを行うための処理部, および 6 軸ロボットとパネル取付け台を固定するための定盤 からなる。定盤上にはパネル取付け台上のパネルをロ ボット座標系に正しく位置決めするための位置決め治 具が設けられている。また処理部は, 三次元視覚セン サの出力を処理し寸法を計算するためのパソコン, 後 述する検査ファイルの作成のための外部記憶装置とイ メージスキャナなどからなる。

図 11 は, この検査システムによる検查の処理の流 れを示している。まず，パネル取付け台の基準面を， 定盤上の位置決め治具にあてがってパネルを固定す る。次に, 検査対象のパネルについての検査ファイル を外部記憶装置から読み込む。読み込んだ恈査ファイ ルで指示される計測部位に, 三次元視賞センサを 6 軸 ロボットで移動・位置決めする。位置決め後, パネル と基準ブロックにスリット光を投射する。得られた反 射光画像に途切れがある場合には，途切れのない反射 光画像が得られるように，6軸ロボットにより三次元 視覚センサの姿勢を変え, スリット光の投射角度の制 御を行う。角度制御により途切れのない反射光画像を 得た後, 投射スリット光の強度制御を行って, 反射光 画像の線幅を適正な值にする。

このようにして, 良好な反射光画像を得た後, パネ ルと基準ブロックについての三次元座標を検出し，こ れより寸法定義点を決定する。なお，上述の角度制御 を, 検查時間で制限される所定の回数まで絽返し行っ ても画像の途切れがなくならない場合は, 図 4 で示し た円のあてはめにより途切れ部分の三次元座標を推定 した後, 定義点を決定する。次に, 決定した定義点の 


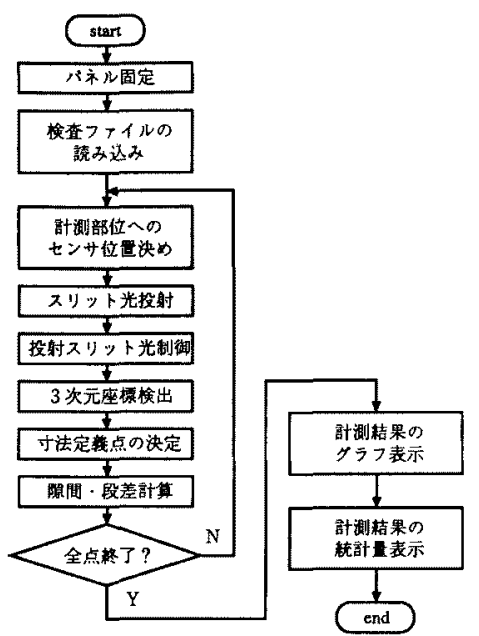

図 11 検查システムの処理の流れ

Fig. 11. Flowchart of the inspection procedure using developed system.

三次元座標からすき間・段差を計算する。すき間・段 差の計湘結果の出力はグラフ表示と統計量表示により 行う。グラフ表示は, 計剆結果の正寸值とのずれをパ ネル外形に沿って表示する。また，統計量として，正 寸值からのずれについての平均值や偏差を出力する。

図 12 は検查ファイルの作成の手覑を示す。検査フ アイルは，パネル検查に必要な情報が登録された表 で，各パネルごとにあらかじめ作成される。これには 計測結果の表示のためのパネル外形図，パネルの複数 の計測部位についての測定の順番，それぞれの計湘部 位の端部形状のタイプとすき間：段差の正寸值，そし て，三次元視覚センサを計測部位に位置決めるるた のロボットの位置情報が登録される。

パネル外形図はイメージスキャナから入力する。ま た，ロボットの位置情報の登録は，基準ブロック上に 記された計測部位に三次元視覚センサのスリット光が 正しく投射されるようにロボットを位置決めし，この ときのロボットの位䈯を外部記憶装置に記憶させて行 亏。

\section{4. 評価実験}

$\langle 4 \cdot 1\rangle$ 方法途切れのない反射光画像を得 るための投射スリット光制御の有効性の検証と，投射 スリット光制御を行ったときの寸法計測精度の評価を 行うため，開発したシステムを用いて塞験を行った。

投射スリット光制御の有効性の検証は，パネル端部 に光沢のある実パネルを対象に，投射スリット光制御

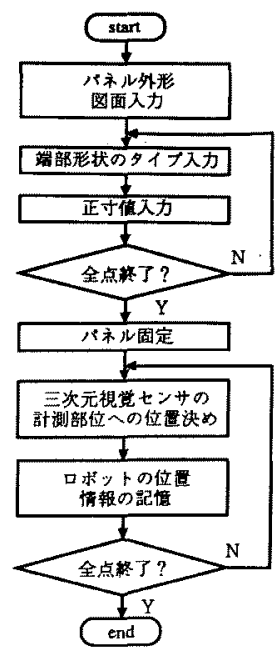

図 12 検查ファイルの作成の手順

Fig. 12. Flowchart of preparing the inspection table.

を行わない場合と行った場合のそれぞれについて，三 次元視覚センサにより検出された反射光画像を比較す ることで行う。

寸法計測精度の評価は，実パネルを対象に行う。寸 法計測部位は, 図 2 に示される 4 種類の端部形状のそ れぞれについて 20 点とし, 図 2 の (2)〜 (4)の端部 形状については，パネル端部に光沢が発生している部 位とする。評洒は，この計測部位のすき間と段差につ いて，その真值と本システムによって投射スリット光 制御を行って得た湘定値とを比較することで行う。す き間と段差の真值は，本システムによる测定後，パネ ルに樹脂を流し込んで製作したレプリカの断面を万能 投影機で観測して求める。

〈4・2〉結 果 図 13 は投射スリット光制御の 有効性の検証害験結果である。(a)図は, 図 2(4)の 端部形状のパネルに，投射スりット光制御を行わない であらかじめ設定した一定角度で一定強度のスリッ 卜光を投射したときの反射光画像の例を示している。 この図より，パネルの光沢のため端部に途切れが発生 していることがわかる。更にこの画像では，途切れて いない部分についても，線幅は適正な幅よりも細く撮 像されている。

図13(b)は，同じパネルについて途切れがなくな るように投射スリット光の角度制御を行い, 更に, 強 度制御を行った後の反射光画像を示している。これら の制御により，画像の途切れがなくなっていること と，画像の線幅が制御前に比べ広く撮像されているこ 


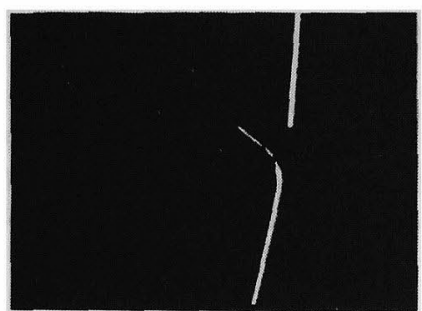

(a ) 端部に途切れのある反射光画像

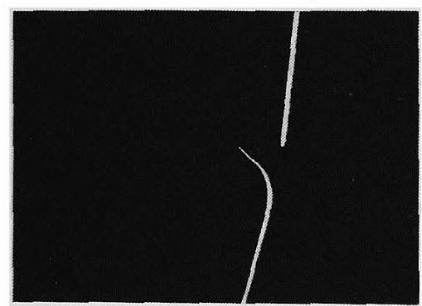

（b）投射スリット光制御後の反射光画像

図 13 投射スリット光制御の有効性 Fig. 13. Validity of controlling slit light projection angle and brightness.

とがわかる。

以上の実験結果から，投射スリット光制御がパネル の光沢による反射光画像の途切れなどの改善に有効で あることが確認された。

図 14 に計測精度の実験結果を示す。(a)図がすき 間, (b)図が段差の結果である。横軸はレプリカから 求めた真值, 縦軸は本システムによる測定誤差であ る。ここで, 測定誤差は測定值から真值を引いた值で ある。端部形状の違いは口， いる。この実験結果より，すき間と段差とも，端部形 状の違いによる有意差はなく，1）４）の全端部形状

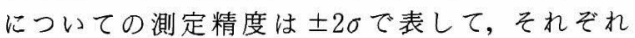
$\pm 0.15 \mathrm{~mm}, \pm 0.1 \mathrm{~mm}$ であることがわかる。パネル を製作するときに許容されている寸法誤差（以下, 許 容詿差という）は，パネルと基準ブロックとのすき 間・段差で表して，いずれも $\pm 0.5 \mathrm{~mm}$ であり，その 寸法を測定するうえでの目標精度は許容誤差の $1 / 3$ 以 下である $0.17 \mathrm{~mm}$ に決められている。

上述の測定精度結果は，この目標精度を満たしてお りここれより開発した検査方式と検査システムの有効 性が確認された。

表 2 に検査システムの性能をまとめて示す。検査対 象は自動車用のドアパネルなど 30 種類である。すき 間と段差の計測範囲は, すき間が $1 \sim 8 \mathrm{~mm}$, 段差が

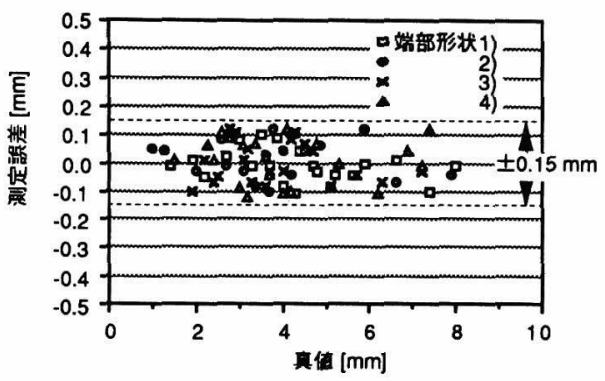

(a) すき間

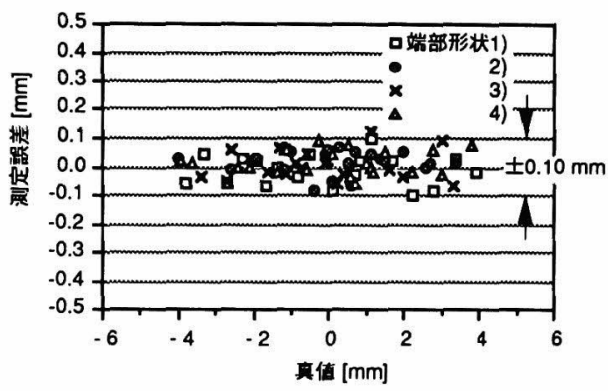

(b) 段差

図 14 計測精度

Fig. 14. Accuracy of dimension inspection.

表 2 検査システムの性能

Table 2. Performance of the inspection.

\begin{tabular}{|c|c|}
\hline パネル種類 & ドアパネルなど 30 種類 \\
\hline 計測範囲 & すき間： $1 \sim 8 \mathrm{~mm}$ ，段差： $-4 \sim 4 \mathrm{~mm}$ \\
\hline 計測精度 & すき間： $\pm 0.15 \mathrm{~mm}$ ，段差： $\pm 0.10 \mathrm{~mm}$ \\
\hline 計測 時間 & 6 秒 $/ 1$ 測定点 \\
\hline & (位垚決め：4 秒、測定： 2 秒) \\
\hline
\end{tabular}

-4〜4 mmであり，計測精度は，すき間がさ0.15 mm， すき間が士0.10 mmである。このシステムによる 1 部位の計測時間は 6 秒で，このうち，ロボットによる 三次元視覚センサの位置決めと姿勢制御が 4 秒, 三次 元視覚センサによる測定が 2 秒である。この 1 部位あ たりの計測時間は, 従来, 人手によって行われていた 場合を約 $1 / 5$ に短縮しており，検査の大幅な高速化が 達成されている。

\section{5. ま と め}

自動車パネルの仕上り寸法を検査するために，三次 元視覚センサを用いた検查方法と, 同法による自動車 パネル寸法検查システムを開発した。

考案した検査方法は，検査すべきパネルと基準ブロ ック間に三次元視覚センサのスリット光を投射して,

電学論C, 112 巻 2 号, 平成 4 年 
その反射光画像に円をあてはめ, その円弧端点を算出 し, これから種々の曲率をもつパネルについて正確に 隙間と段差を計測し検査する方式である。更に，曲げ 加工などで生ずるパネルの光沢のため反射スリット光 画像に途切れが生じたときには，スリット光の投射角 度と投射強度の制御によって良質な画像に改善して, 上記の方法に基づいて検査する。

この方法を用いた検査システムは，三次元視覚セン サを計測部位にロボットにより位置決めし，パネルと 基準ブロック間のすき間と段差を計測する。このシス テムは, 30 種類の自動車パネルの寸法を，1 部位あ たり 6 秒の時間で，精度 $\pm 0.15 \mathrm{~mm}$ 以内で計測する ことができる。

三次元視覚センサとこの検查方式を用いた自動車パ ネル寸法検査システムは，実際の工程で活用され，車 の高品質化に貢献している。

(平成 3 年 8 月 28 日受付)

\section{文献}

(1) Y. Sakamoto \& K. Yamamoto: "Development of a Car Body Inspection System", Proc. of SAE/ESD Interna tional Computer Graphics Conference, p. 101 (1987)

(2) G. Seliger, W. Felsing, K. D. Lennartz \& H. Trilk: "Laser scanning for flexbilization of robotic assembly cells", Proc. of Int. Conf. on Robot Vision and Sensory Controls, p. 307 (1988)

(3) W.S. Wilson: "The Role of Vision in a Dimensional Control Strategy", Proc. of Vision ' 85, p. 7 (1985)

(4) 高木・小島・高草木. 粟根・吉岡：「レーザー応用形状計測 装置」, 日立評論, 68,73 (昭 $61-3$ )

（5）服部・久保・坂本・渡辺：「自由曲面における非接触型三次 元計測」，三菱電機技報，62，73(昭 63-4)

(6) M. Rioux: "Laser Range Finder based on snchronized Scanner", Appl. Opt., 23, 3837 (1984)

(7) R. F. Livingston, A. F. Tulal \& M. R. Thomas: "Application of 3-D Vision to the Measurement of Marince Propel lers", Proc. of Vision '87, p. 10 (1987-06)

（8）小関・樋口・山本：「三次元視賞センサを用いた自動車部品 の寸法検査システム」, 電学論 C, 111, 249 (平 3-6)

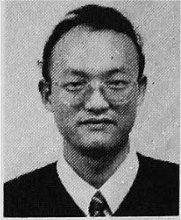

\section{樋口和 則 (正員)}

昭和 61 年名古屋大学大学院修士課程 修了。同年(株)豊田中央研究所入社。以 来，画像処理を用いた三次元計測・認識 の研究と開発に従事。現在, 同研究 8 部 所属。電子情報通信学会, 精密工学会会員。

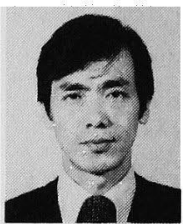

\section{小関 修（正員）}

昭和 56 年名古屋工業大学大学院修士 課程修了。 41 年(株)豊田中央研究所入 社。以来, 自動車用マイクロ波レーダ,

自動車用電子機器の電磁障害, 画像処理 を用いた三次元計測・認識の研究と開発に従事。現在，同 研究 8 部研究員。電子情報通信学会, 計測自動制御学会, 精密工学会会員。

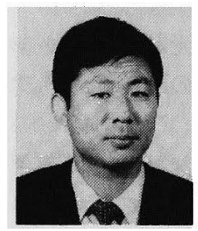

山本新 (正員)

昭和 40 年岐阜大学工学部電気工学科 卒業。同年(株) 豊田中央研究所入社。以 来, 電気自動車の制御, 自動車用電子機 器の電磁障害, 画像処理を用いた三次元 計測・認識および無人搬送システムの視覚に関する研究と 開発に従事。59 年 IEEE-VTS Paper Award 受賞。現在, 同研究 8 部主席研究員。工学博士。情報処理学会, 日本口 ボット学会, 精密工学会自動車技術会会員。 